\title{
ARE MUSLIMS PRACTISING MODERATION IN THEIR FINANCIAL DECISIONS?
}

\author{
Roslily Ramlee*, Sharifah Raihan Syed Mohd Zain, and Wan Rohaida Wan Husain \\ Kulliyyah of Economics and Management Sciences, International Islamic University \\ Malaysia, P.O. Box 10, 50728 Kuala Lumpur, Malaysia \\ *Corresponding author: roslily@iium.edu.my
}

Published online: 20 March 2019

To cite this article: Ramlee, R., Syed Mohd Zain, S.R., and Wan Husain, W.R. (2019). Are Muslims practising moderation in their financial decisions? Asian Academy of Management Journal, 24(Supp. 1), 157-170. https://doi.org/10.21315/aamj2019.24.s1.11

To link to this article: https://doi.org/10.21315/aamj2019.24.s1.11

\begin{abstract}
Statistics and a survey of the literature revealed the existence of a massive problem in the financial prudence of Malaysians, including Muslims. One glaringly prominent aspect is the absence of a spiritual/religious interventionist approach in exploring the lack of consumer awareness that led to the present situation. Instead of attempting to solve the problem through brute economic policies, a wasatiyyah-oriented approach is warranted for informing consumers of their religious obligation to avoid profligate spending and adopt moderation in financial matters. Hence, the objective of this study is to examine the practice of moderation (the concept of wasatiyyah) among Muslims consumers in their financial decision-making. Primary data were collected through a self-administrated survey on a selected group of Muslim consumers. A relevant statistical software was employed to perform exploratory-factor analysis (EFA) through principal-component analysis (PCA), confirmatory factor analysis (CFA), and structural equation modelling (SEM) on the collected data. The findings demonstrated that moderation (wasatiyyah) partially mediates the relationship between materialism and financial decisions. Consequently, Muslim consumers who practice moderation while making their financial decisions are more conscious of their credit management and thus spend according to their means.
\end{abstract}

Keywords: moderation (wasatiyyah), Muslim consumers, financial decision, financial literacy, materialism

(C) Asian Academy of Management and Penerbit Universiti Sains Malaysia, 2019. This work is licensed under the terms of the Creative Commons Attribution (CC BY) (http://creativecommons. org/licenses/by/4.0/). 


\section{INTRODUCTION}

The use of wasatiyyah (the concept of moderation) in resolving the complexities involved in planning how individuals and/or households earn, spend, and invest their money is an essential element that Muslim consumers should consider concerning financial decisions. There is no doubt of the importance of money, credit, and assets in life; however, excessive use by consumers of credit, for example, may result in severe consequences, such as stress, insolvency, health complications, psychiatric disorders, and marital and family strife. The two sources of personal financial obligations are secured-debt, such as home mortgages and automobile loans, and unsecured debt, such as credit cards, personal loans, medical debt, payday loans, title loans, and small-business loans. One type of unsecured debt that has contributed significantly to the financial crises experienced by consumers is credit card debt (Hamilton, Noh, \& Adlaf, 2009; Smith, Richards, Shelton, \& Malespin, 2015). The main question examined in this study is to what degree Malaysian Muslims are practising wasatiyyah in all aspects of their financial decisions.

Wasatiyyah is a derivation of an Arabic word that loosely means excellent, moderate, just, and professional (Ismail, Azmi, Al-Haddad, Basir, \& Nayan, 2017), and it is one of the emphasised concepts in the primary sources of Islamic epistemology, the al-Qur'an and the hadith (Hanapi, 2014). The concept of wasatiyyah is rooted in Islamic epistemology, and it is a religious belief that plays an important role in people's day-to-day behaviour. Consequently, knowing to what degree Muslim consumers in Malaysia are observing wasatiyyah in their financial decisions would improve financial discussions at several levels, such as determining how wasatiyyah could improve financial and consumption decisions in Malaysia (Iannaccone, 1998).

Furthermore, the researchers are particularly concerned on the extravagant or wasteful acts of Malaysian Muslim consumers in the use of what has been permitted by Islam, known as israf in the Islamic tradition. Briefly, Islam prohibits an excessive way of life, and therefore wasatiyyah is needed to ensure that consumers always operate within the limits of moderation when satisfying or attempting to satisfy their needs. For example, taking on excessive debt to satisfy several needs, consuming excessive food, and wasting resources (even for religion) are all prohibited in Islam. As such, every kind of excessive behaviour, including emotional, social, cultural, and financial, is covered by this concept and is prohibited (Kamali, 2015).

Meanwhile, Malaysians' household debt has been on an increasing trend since the 1997 Asian financial crisis, which could be attributed to the shifting of banking 
institutions from corporate business to household financing (Khan, Abdullah, \& Samsudin, 2017; Norhana \& Hua, 2009). According to CEIC data, the proportion of Malaysian household debt to the gross domestic product (GDP) was $88.30 \%$ in $2016,89.02 \%$ in $2015,86.78 \%$ in 2014 , and $86.16 \%$ in $2013^{1}$. Given this alarming ratio of household debt to GDP, Malaysia has among the highest levels of household debt among Asian economies, according to a report by MIDF Amanah Investment Bank Berhad (2016). Epidemic of inappropriate personal financial behaviour among Malaysian consumers has produced a need for effective measures to provide a solution to the problem. Thus, consumers' religious identity has been identified as having a practical influence on their financial decisions (Fam, Waller, \& Erdogan, 2004; Hess, 2012; Jaiyeoba \& Haron, 2016). The concept of wasatiyyah together with the influence of materialism and financial literacy were used in this study to investigative Malaysian Muslim consumers' financial decisions. The findings showed that wasatiyyah partially mediated the relationship between materialism and financial decisions but did not mediate the relationship between financial literacy and financial decisions.

While this study may be one of the first to investigate whether Malaysian Muslim consumers practice wasatiyyah in their financial decisions, it is believed that the present study will offer substantial benefits to both academicians and practitioners. Through this study, the researchers provide fresh insight and deeper understanding of whether Muslim consumers in Malaysia practice wasatiyyah in their financial decisions. Similarly, this study may serve as a guide to Malaysian Muslim consumers when they are making financial decisions. It could also serve as a reference point for relevant authorities when they are making pertinent decisions and as a pioneering study for future researchers to build upon.

\section{LITERATURE REVIEW}

There has been a plethora of literature proving that financial decisions are an essential component of consumers' economic behaviours (Hopper, 1995). As mentioned, Malaysians' household debt has been on the increasing trend, the extension of credit lending to the Malaysian households and other individuals has proliferated the use of the loan to satisfy numerous needs, even without a necessary financial budget. People's needs for housing, vehicles, motorcycle, education, vacation, or other daily upkeep may not be achievable due to lack of money (Garling, Kirchler, Lewis, \& Raaij, 2009). In such a case, if people are not willing to postpone the need of these materials to date when necessary saving would have been accumulated, they may decide to use credit to fulfil these needs. The rise of compulsive consumptions have been supported by the postmodern society such as 
Malaysia (Kaplan, 2014) and facilitated by growing availability of credit purchases (Neuner, Raab, \& Reisch, 2005; Tokunaga, 1993). The endemic reckless financial decision among consumers as evidenced by excessive debts (Hess, 2012) has called for practical measures in providing a solution to the above ordeal. Thus, given that consumer's religious identity has been noticed in the literature as having practical influence on consumers' financial decisions (Fam et al., 2004; Hess, 2012), the concept of wasatiyyah together with materialism, financial literacy, and personal characteristics were reviewed in this study to investigative consumers' financial decisions.

Materialism has been discussed in the literature concerning a psychiatric disorder in which buying behaviour is excessive and impulsive in nature, even in the face of adverse consequences (Dittmar, 2008). Richins and Dawson (1992) conceptualised material values as covering three essential domains: (1) using others' or one's own possessions to judge the level of success; (2) the belief that acquisition and possessions bring about happiness and satisfaction in life; and (3) the centrality of possessions in a person's life, a way of life and the holding of opinions based entirely on material interests to the neglect of spiritual matters. Empirically, Watson (1998) examined the relationships between materialistic values, attitudes towards debt, and levels of indebtedness in New Zealand. His results indicated that high levels of materialism were positively related to attitudes towards spending and debt. Similarly, Ponchio and Aranha (2008) examined the influence of materialism on consumer indebtedness among 450 low-income households in a poor area of São Paulo in Brazil. A logistic regression model confirmed materialism as a behavioural variable that could be used to forecast the probability of people accruing consumption-related debt. Additionally, Gardarsdóttir and Dittmar's (2012) study revealed that individuals who endorse materialistic values usually have more financial worries, greater tendencies towards compulsive buying and spending, and worse money-management skills. It was also found that while controlling for income and money-management skills, the amount of debt can be linked to materialism. Nepomuceno and Laroche (2015) investigated how materialism and anti-consumption lifestyles correlated with personal debt and account balances in Brazil. The study found that the happiness dimension of materialism was positively related to personal debt and negatively correlated with account balances, suggesting that those who are materialistic in nature are also prone to indebtedness.

Materialistic behaviour is expected to be worse among consumers with inadequate financial knowledge. Financial-literacy skills help consumers navigate the financial world, have less chance of being misled on financial matters, and make informed decisions about their money (Beal \& Delpachitra, 2003). Making financial 
decisions, either on asset-building, debt management, or consumption requires that consumers be able to perform calculations, including complex ones; however, there is burgeoning literature claiming that financial illiteracy is a common phenomenon in diverse economic settings (Fonseca, Mullen, Zamarro, \& Zissimopoulos, 2012). According to Beal and Delpachitra (2003), the symptoms of insufficient financial literacy in a country include, among others, rising individual debt levels with overuse of credit cards, irresponsible overspending on consumption, foolish commitment to get-rich-quick schemes, and using personal loans for consumption.

Brown and Graf (2012) found that financial literacy is lower among low-income, female, and immigrant households. Moreover, young households are less familiar with the concept of inflation, while the concepts of compound interest and risk diversification are less known to retirees. Their study also showed that financial literacy was highly correlated with voluntary retirement saving, financial-market participation, and mortgage borrowing. Beckmann (2013) found that financial literacy was positively related to household saving and investment in Romania. Meanwhile, French and McKillop (2016) investigated the components of financial literacy - numeracy and money-management skills - in relations to consumer debt and household net found that money-management skills were essential determinants of financial outcomes, while numeracy was found to play a minimal role in this regard.

As previously stated, practising wasatiyyah is expected to improve financial and consumption decision among Muslims consumers. However, there are few empirical financial studies, if any, on the application of wasatiyyah, especially in financial decisions. To consider those areas where wasatiyyah has been applied, a qualitative study by Hanapi (2014) used a content-analysis method to identify and analyse the wasatiyyah concept in Islamic epistemology and its implementation in Malaysia. The author found that the use of wasatiyyah was comprehensive and indeed different from political slogans, such as "Islam Hadhari", "Clean, Efficient and Trustworthy", and other implementations, which are transient or temporary in nature. Besides, Wan Husin (2013) investigated the relationship between wasatiyyah and the values of budi-Islam (Islamic values) in reinforcing Malaysian ethnic relations. The finding ascertained that wasatiyyah was used to reinforce the Malay leader's traditional administrative approach when dealing with other ethnic groups in the community.

A study by Ismail et al. (2017) discussed the potential of the wasatiyyah concept for human sustainability in Malaysian civil-service practices. The authors found that the wasatiyyah value concept could be used to extend and enrich the value of human sustainability and the quality of civil-service practices in Malaysia. 
They also showed that wasatiyyah had indirectly embedded in Malaysian civilservice practices. In addition, Mohd Khambali@Hambali et al. (2015) showed that the wasatiyyah concept has nurtured religious tolerance, fostered harmony, and has significant influence on the relationship among Muslims, newly converted Muslims, and non-Muslims in the country. The concept also has a strong link with the value of akhlaq, which is part and parcel of the Muslim community.

While there are examples in the literature suggesting that materialism and financial literacy may impact financial decisions (Ali, McRae, \& Ramsay, 2014; Muzafari, Mowlaie, \& Bahmani, 2016), this research incorporated wasatiyyah as a mediating variable in the relationship between materialism and financial decisions, as well as in the relationship between financial literacy and financial decisions. The conceptual framework is shown in Figure 1. Research hypotheses for this study are as follows:

H1: Wasatiyyah mediates the influence of materialism on financial decisions made by Muslim consumers.

$\mathrm{H} 2$ : Wasatiyyah mediates the influence of financial literacy on financial decisions made by Muslim consumers.

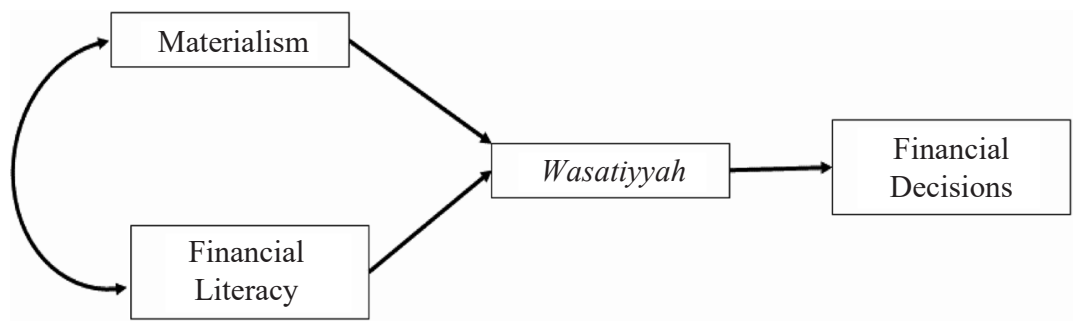

Figure 1. Conceptual framework

\section{METHODOLOGY}

This study adopted a quantitative research design which is also the common approach adopted previously by researchers to investigate wasatiyyah, materialism, financial literacy, and financial decisions (Ali et al., 2014; Khan et al., 2017; Mujani, Mazuki, Aziz, \& Rozali, 2014; Muzafari et al., 2016; Smith et al., 2015). Questionnaire for this study was developed based on relevant measurement items as tested and reported in the literature following the research framework presented 
in Figure 1. Furthermore, the measurement items for understanding and adoption of wasatiyyah were developed based on the interpretation (tafsir) of Surah al-Furqan (25:67) by A'la Mawdudi (2000). The data were collected from Muslim consumers in Malaysia focusing on public and private employees working in Putrajaya and Klang Valley areas. The questionnaire, which was used to assess to what degree respondents agreed or disagreed with the measurement items, employed a 5-point Likert-type scale, ranging from strongly disagree (1) to strongly agree (5). The data were then analysed using the Statistical Package for the Social Sciences (SPSS) and Analysis of Moment Structures (AMOS). Specifically, data screening, assumptions, validation, and reliability testing underlying this study, as well as exploratory-factor analysis (EFA), were all performed in SPSS. AMOS was used to perform confirmatory-factor analysis (CFA) and structural equation modelling (SEM). Additional illustration on the investigations conducted was provided within each subsection of the next segment.

\section{RESULTS AND DISCUSSION}

\section{Sample Characteristics}

A total of 450 surveys were distributed and 299 surveys were collected, giving a response rate of $66.44 \%$. Table 1 shows the profile of the respondents. The majority of the respondents were female $(67.9 \%)$ and most of them were college and university graduates (73.9\%). Most respondents were between 20 and 40 years old (66.7\%), and most of them earned either less than RM3,000 monthly (35.1\%) or between RM3,001 and RM6,000 monthly (32.4\%). The average score on financial knowledge was $42.7 \%$. The table also shows that $88.3 \%$ of the respondents were aware of the wasatiyyah concept and that $94 \%$ agreed that they practice moderation in their spending. This finding is consistent with the finding of Mujani et al. (2014).

\section{Exploratory Factor Analysis (EFA)}

For the objectives of testing unidimensionality and verifying the number of underlying factors, EFA with varimax rotation was conducted. Items with a loading of smaller than 0.6 were accordingly deleted, resulting in 24 items shortlisted as significant (Table 2). The sampling was adequate, and correlationship between the variables was sufficient based on the Kaiser-Meyer-Olkin (KMO) test score of 0.818 and significant Bartlett's test of sphericity at $p<0.0001$. Hence, the suitability of the collected data for factor analysis was verified. 
Table 1

Descriptive statistics

\begin{tabular}{lccc}
\hline & Percentage & Percentage \\
\hline Gender & & Income $(\mathrm{RM})$ & \\
Male & 32.1 & $<3,000$ & 35.1 \\
Female & 67.9 & $3,001-6,000$ & 32.4 \\
Age (years) & & $6,001-10,000$ & 20.7 \\
$20-30$ & 32.5 & $>10,000$ & 11.7 \\
$31-40$ & 34.2 & Employment & \\
$41-50$ & 26.0 & Corporate & 28.5 \\
$51-60$ & 5.8 & Government & 49.8 \\
$>60$ & 1.4 & Other & 21.7 \\
Educational background & & Financial knowledge & \\
Non-graduate & 26.1 & Very high & 11.9 \\
Diploma & 24.7 & Above average & 20.3 \\
Degree & 27.1 & Average & 42.7 \\
Postgraduate & 22.1 & Limited & 25.1 \\
Aware of wasatiyyah & & Practice moderation & \\
Yes & 88.3 & Yes & 94.0 \\
No & 11.7 & No & 6.0 \\
\hline
\end{tabular}

Table 2 tabulates evidence on the applicable number of constructs and the degree of variance explained by the identified constructs cumulatively. It was confirmed that by using the first four components, $52.72 \%$ of the variance in the collected data could be explained. All loadings were at least 0.60 on their respective constructs; proving a very good degree of discriminant validity. The names for the constructs were given based on the nature of the items being loaded on each and also consistent with the connotation of the items when they were tested in the questionnaire.

\section{Structural Equation Modelling (SEM): Measurement Model}

As the EFA justified the four underlying constructs and proved a sufficient correlation between the variables, the next step was to confirm the identified groupings using a two-stage SEM technique. The measurement model had fit indices that were all above the recommended thresholds. In particular, the normed $\chi^{2}$ for the reported model was 1.840 , the comparative-fit index (CFI) was 0.914 , and the root means error square of approximation (RMSEA) was 0.054. It was therefore confirmed that the grouped items indeed belonged to the identified constructs, a required verification that the structure is fit for testing hypotheses in the second stage of SEM. 
Table 2

Results of EFA for the adoption of wasatiyyah among the public

\begin{tabular}{|c|c|c|c|c|}
\hline \multirow{2}{*}{ Items (variables) } & Factor 1 & Factor 2 & Factor 3 & Factor 4 \\
\hline & F/Literacy & Materialism & Wasatiyyah & F/Decision \\
\hline L4 & 0.790 & & & \\
\hline L2 & 0.769 & & & \\
\hline L9 & 0.735 & & & \\
\hline L1 & 0.729 & & & \\
\hline L5 & 0.717 & & & \\
\hline L8 & 0.693 & & & \\
\hline L10 & 0.689 & & & \\
\hline L11 & 0.658 & & & \\
\hline L7 & 0.608 & & & \\
\hline M1 & & 0.684 & & \\
\hline M13 & & 0.677 & & \\
\hline M5 & & 0.676 & & \\
\hline M2 & & 0.661 & & \\
\hline M10 & & 0.659 & & \\
\hline M15 & & 0.653 & & \\
\hline M4 & & 0.643 & & \\
\hline W16 & & & 0.744 & \\
\hline W7 & & & 0.721 & \\
\hline W14 & & & 0.674 & \\
\hline W10 & & & 0.662 & \\
\hline W2 & & & 0.638 & \\
\hline $\mathrm{F} 1$ & & & & 0.754 \\
\hline $\mathrm{F} 2$ & & & & 0.693 \\
\hline F3 & & & & 0.669 \\
\hline Initial eigenvalue & 4.756 & 3.695 & 2.361 & 1.840 \\
\hline$\%$ of variance & 19.818 & 15.397 & 9.837 & 7.665 \\
\hline Cumulative \% & 19.818 & 35.215 & 45.052 & 52.718 \\
\hline
\end{tabular}

\section{Structural Equation Modelling (SEM): Structural Model}

SEM was carried out to test the hypotheses. As depicted in Figure 2, the direct causal relationship between materialism and financial decisions was given a standardised regression weight of 0.39 , while that relationship mediated by wasatiyyah was given a standardised regression weight of -0.0648 . Based on Table 3 , the causal relationship for wasatiyyah-materialism was 0.36 and significant at $p<0.001$, while for wasatiyyah-financial decisions directly was -0.18 and significant at 
$p<0.01$. This statistically supports the presence of a partial mediating influence of wasatiyyah on the effect of materialism on financial decisions made by Muslim consumers. It is right considering the effect of wasatiyyah on financial decisions directly, has a negative correlationship. This supports our assumption that understanding wasatiyyah makes people more moderate and prudent in making financial decisions, particularly in spending, taking debt, saving as well as money management. This is also consistent with the emphasis of Surah al-Furqan (25:67): "people who spend moderately are the true believers". It is thus partial influence as even without the presence of wasatiyyah as the mediating variable, the relationship between them is strong (0.39). The identified direct relationship is consistent with the findings of Watson (1998), Gardarsdóttir and Dittmar (2008), and Nepomuceno and Laroche (2015) that materialism has a significant influence on financial decisions related to spending, saving, debt, and money-management skills.

The causal relationship between financial literacy and financial decisions was given a standardised regression weight of 0.21 , while that relationship mediated by wasatiyyah was given a low standardised regression weight of only 0.0072 , i.e., it was identified as not significant. Thus, empirical evidence does not support our second hypothesis, which postulates wasatiyyah enhances the impact of the financial literacy of Muslim consumers on their finance-related decisions. In other words, the adoption of wasatiyyah does not by itself influence one's level of financial knowledge. However, we did obtain empirical evidence for the presence of a strong direct influence of financial literacy and financial decisions consistent with the findings of Brown and Graf (2012), Beckmann (2013), and French and McKillop (2016). The finding reflects that those with high financial literacy are capable of making sounder financial decisions and that being moderate is part of their financial knowledge.

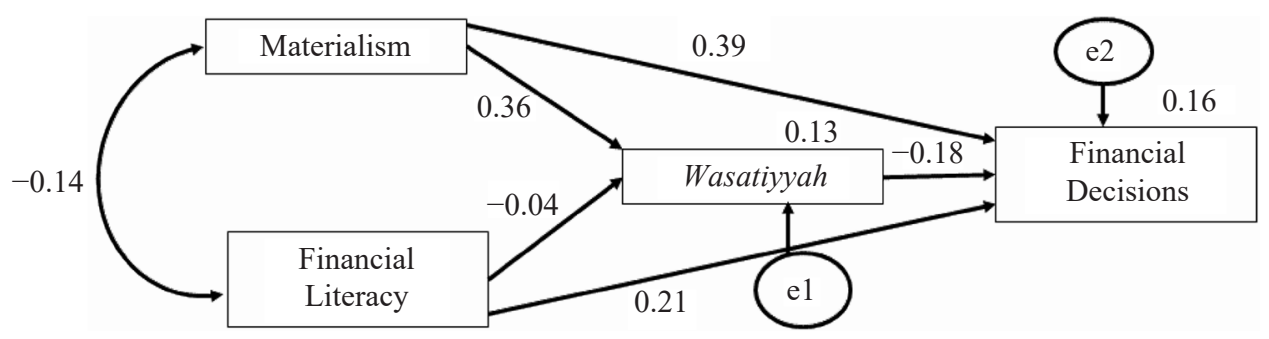

Figure 2. Wasatiyyah as a mediator between materialism or financial literacy and financial decisions made by the public 
Table 3

Estimates of the hypothesised model

\begin{tabular}{llccc}
\hline Structural path & $\begin{array}{c}\text { Hypothesised } \\
\text { relationship }\end{array}$ & $\begin{array}{c}\text { Std. reg. } \\
\text { weight }\end{array}$ & S.E. & $p$ \\
\hline Wasatiyyah $\rightarrow$ Materialism & Supported & 0.36 & 0.049 & $0.000^{* * *}$ \\
Wasatiyyah $\rightarrow$ Financial literacy & Not supported & -0.04 & 0.103 & 0.522 \\
Wasatiyyah $\rightarrow$ Financial decisions & Not hypothesised & -0.18 & 0.067 & $0.002^{* *}$ \\
Materialism $\rightarrow$ Financial decisions & Not hypothesised & 0.39 & 0.059 & $0.000^{* * *}$ \\
Financial Literacy $\rightarrow$ Financial decisions & Not hypothesised & 0.21 & 0.116 & $0.000^{* * *}$ \\
\hline
\end{tabular}

Note: ${ }^{*},{ }^{* *}$, and ${ }^{* * *} 10 \%, 5 \%$, and $1 \%$ significant level, respectively

In brief, the findings of this study have a theoretical implication on spending and consumption behaviour of consumers. Practising wasatiyyah should be considered a unique mediator to influence the financial decisions of Muslim consumers. This is consistent with Fam et al. (2004), Hess (2012), and Jaiyeoba and Haron (2016) that consumers' religious identity and teaching influence their financial decisions. Additionally, practising wasatiyyah to a certain degree has a practical influence on the financial decisions of Muslim consumers. This is particularly true as the descriptive statistic shows that $88.3 \%$ of respondents were aware of wasatiyyah concept and $94.0 \%$ agreed that they indeed practiced moderation in their spending. The finding demonstrates that most of the Muslim consumers were aware that their religion forbids an extravagance and wasteful way of life and they must always operate within the limits of moderation when satisfying or attempting to satisfy their needs. However, a strong direct effect of materialism on financial decisions calls for further efforts to promote moderate spending behaviour, improving saving, and reducing consumption-related debts among Muslim consumers. More awareness campaigns on a moderate way of life, prudent financial management, and importance of having more saving among the Muslim consumers should be lauded at various levels, starting from the school children to public. This awareness would enhance Muslims' financial literacy and ultimately improve their financial decisions making. Hence, being moderate (wasatiyyah) is a value that should be imbued and inculcated in every Muslim.

\section{CONCLUSION}

We have demonstrated the importance of a wasatiyyah-oriented approach in improving the financial decisions of Malaysian Muslim consumers. To reiterate, this study investigated the practice of moderation (the concept of wasatiyyah) among Muslims consumers in their financial decision-making. The literature 
shows that there is a massive problem concerning the financial prudence of Malaysians, particularly Muslims. Our research was conducted to ascertain whether adoption of wasatiyyah would be able to mediate this problem, and the results showed that wasatiyyah partially mediated the relationship between materialism and financial decisions but did not mediate the relationship between financial literacy and financial decisions. This result suggests that Muslim consumers who practice moderation while making their financial decisions are more conscious of their credit management; hence, they spend in accordance with their means. Consequently, the researchers have demonstrated that practising wasatiyyah in making financial decisions would probably lessen Malaysians' worrying financialprudence problem.

\section{ACKNOWLEDGEMENTS}

This work was funded by Research Initiative Grant Scheme (RIGS) of International Islamic University Malaysia (IIUM) (grant number: RIGS15-059-0059). We would like to thank IIUM for the fund provided to embark on this research.

\section{NOTE}

1. Retrieved 15 March 2018 from https://www.ceicdata.com/en/indicator/malaysia/ household-debt--of-nominal-gdp.

\section{REFERENCES}

A'la Mawdudi, S.A. (2000). Towards understanding the Quran volume 7: Surahs AlFurqan to Al-Qasas (Z. Ansari, Trans.). UK: The Islamic Foundation.

Ali, P., McRae, C.H., \& Ramsay, I. (2014). Financial literacy and financial decision-making of Australian secondary school students. Australian Business Law Review, 42(3), 228-233.

Beal, D.J., \& Delpachitra, S.B. (2003). Financial literacy among Australian university students. Economic Papers: A Journal of Applied Economics and Policy, 22(1), 65-78. https://doi.org/10.1111/j.1759-3441.2003.tb00337.x

Beckmann, E. (2013). Financial literacy and household savings in Romania. Numeracy, 6(2), Article 9. https://doi.org/10.5038/1936-4660.6.2.9

Brown, M., \& Graf, R. (2012). Financial literacy, household investment and household debt: Evidence from Switzerland (Working Paper on Finance No. 13/1). Switzerland: Swiss Institute of Banking and Finance. 
Dittmar, H. (2008). Consumer culture, identity and well-being the search for the "good life" and the "body perfect" (1st ed.). London: Psychology Press.

Fam, K.S., Waller, D.S., \& Erdogan, B.Z. (2004). The influence of religion on attitudes towards the advertising of controversial products. European Journal of Marketing, 38(5/6), 537-555. https://doi.org/10.1108/03090560410529204

Fonseca, R., Mullen, K.J., Zamarro, G., \& Zissimopoulos, J. (2012). What explains the gender gap in financial literacy? The role of household decision making. Journal of Consumer Affairs, 46(1), 90-106. https://doi.org/10.1111/j.17456606.2011.01221.x

French, D., \& McKillop, D. (2016). Financial literacy and over-indebtedness in lowincome households. International Review of Financial Analysis, 48, 1-11. https:// doi.org/10.1016/j.irfa.2016.08.004

Gardarsdóttir, R.B., \& Dittmar, H. (2012). The relationship of materialism to debt and financial well-being: The case of Iceland's perceived prosperity. Journal of Economic Psychology, 33(3), 471-481.https://doi.org/10.1016/j.joep.2011.12.008

Garling, T., Kirchler, E., Lewis, A., \& van Raaij, F. (2009). Psychology, financial decision making, and financial crises. Psychological Science in the Public Interest, 10(1), 1-47. https://doi.org/10.1177/1529100610378437

Hamilton, H.A., Noh, S., \& Adlaf, E.M. (2009). Perceived financial status, health, and maladjustment in adolescence. Social Science and Medicine, 68(8), 1527-1534. https://doi.org/10.1016/j.socscimed.2009.01.037

Hanapi, M.S. (2014). The wasatiyyah (moderation) concept in Islamic epistemology: A case study of its implementation in Malaysia. International Journal of Humanities and Social Science, 4(9(1)), 51-62.

Hess, D.W. (2012). The impact of religiosity on personal financial decisions. Journal of Religion \& Society, 14, 1-13.

Hopper, J.S. (1995). Family financial decision making: Implications for marketing strategy. Journal of Services Marketing, 9(1), 24-32. https://doi. org/10.1108/08876049510079862

Iannaccone, L.R. (1998). Introduction to the economics of religion. Journal of Economic Literature, 36(3), 1465-1495. https://doi.org/10.1016/j.religion.2008.01.006

Ismail, S.H.S., Azmi, I.A.G., Al-Haddad, S.L.S.K., Basir, S.A., \& Nayan, I. (2017). The potential of al-Wasatiyyah value concept for human sustainability (HS) in civil service. Humanomics, 33(2), 150-162. https://doi.org/10.1108/H-08-2016-0067

Jaiyeoba, H.B., \& Haron, R. (2016). A qualitative inquiry into the investment decision behaviour of the Malaysian stock market investors. Qualitative Research in Financial Markets, 8(3), 246-267. https://doi.org/10.1108/QRFM-07-2015-0027

Kamali, M.H. (2015). The middle path of moderation in Islam. The Qur'anic principle of wasatiyyah. Oxford, UK: Oxford University Press. https://doi.org/10.1093/ acprof:oso/9780190226831.001.0001

Kaplan, R.D. (2014). Asia's cauldron: The South China Sea and the end of a stable Pacific. New York: Random House.

Khan, H.H.A., Abdullah, H., \& Samsudin, S. (2017). The relationship between household debt composition and GDP in Malaysia. Social Sciences \& Humanities, 25, 289298. 
MIDF Amanah Investment Bank Berhad. (2016). High household debt in Malaysia is not a systemic risk. Retrieved 5 February 2018 from http://www.midf.com.my.

Mohd Khambali@Hambali, K., Sintang, S., Awang, A., Mat Karim, K.N., Abdul Rahman, N.F., Wan Ramli, W.A., Senin, N., Zainal Abidin, A., Ismail, A.Z., Wan Ali, W.Z.K., \& Md. Noor, R. (2015). Al-Wasatiyyah in the practice of religious tolerance among the families of new Muslims in sustaining a well-being society. Humanomics, 33(2), 211-220. https://doi.org/10.1108/H-02-2017-0025

Mujani, W.K., Mazuki, A.A.M., Aziz, A., \& Rozali, E.A. (2014). Society's knowledge of wasatiyyah (moderation) concept. In Y. Zhang (Ed.), 2014 2nd International Conference in Humanities, Social Sciences and Global Business Management (pp. 140-143). Singapore: Singapore Management and Sports Science Institute, Pte. Ltd.

Muzafari, S., Mowlaie, S., \& Bahmani, K. (2016). Relationship between materialism and financial risk with the mediating role of emotions and indebtedness. Journal of Ecophysiology and Occupational Health, 16(3-4), 124-128. https://doi.org/ 10.15512/joeoh/2016/v16i3\&4/14750

Nepomuceno, M.V., \& Laroche, M.(2015). The impact of materialism and anti-consumption lifestyles on personal debt and account balances. Journal of Business Research, 68(3), 654-664. https://doi.org/10.1016/j.jbusres.2014.08.006

Neuner, M., Raab, G., \& Reisch, L.A. (2005). Compulsive buying in maturing consumer societies: An empirical re-inquiry. Journal of Economic Psychology, 26(4), 509522. https://doi.org/10.1016/j.joep.2004.08.002

Norhana, E., \& Hua, T.G. (2009). Household debt in Malaysia. BIS Papers, 46, 107-116. Retrieved 5 June 2017 from http://ideas.repec.org/h/bis/bisbpc/46-12.html

Ponchio, M.C., \& Aranha, F. (2008). Materialism as a predictor variable of low income consumer behavior when entering into installment plan agreements. Journal of Consumer Behaviour, 7(1), 21-34. https://doi.org/10.1002/cb.234

Richins, M.L., \& Dawson, S. (1992). A consumer values orientation for materialism and its measurement: Scale development and validation. Journal of Consumer Research, 19(3), 303-316. https://doi.org/10.1086/209304

Smith, T.E., Richards, K.V., Shelton, V.M., \& Malespin, T.S. (2015). Sirens' call: Understanding poor financial decision making and credit card misuse. Journal of Human Behavior in the Social Environment, 25(8), 897-906. https://doi.org/10.1 080/10911359.2015.1039156

Tokunaga, H. (1993). The use and abuse of consumer credit: Application of psychological theory and research. Journal of Economics Psychology, 14(2), 285-316. https://doi.org/10.1016/0167-4870(93)90004-5

Wan Husin, W.N. (2013). The relationship between the concept of wasatiyyah and the values of budi-islam in reinforcing ethnic relations in Malaysia. International Journal of Social Science and Humanity, 3(6), 528-531. https://doi.org/10.7763/ IJSSH.2013.V3.297

Watson, J.J. (1998). Materialism and debt: A study of current attitudes and behaviors. Advances in Consumer Research, 25, 203-207. Retrieved 2 June 2017 from http://www.acrwebsite.org/search/view-conference-proceedings.aspx?Id=8153 